\title{
ON THE RELATIONSHIP OF FUNDING AND RESEARCH PUBLICATIONS $\neq * *$
}

\author{
MIRANDA LEE PAO \\ School of Information and Library Studies, \\ The University of Michigan \\ 550 East University, Ann Arbor, Michigan 48109-1092 (USA)
}

(Received January 4, 1990)

\begin{abstract}
The impact of a 17 year period of funding in schistosomiasis research on publication outcome was examined. Two productivity and three quality indicators were used to compare the output from the entire population of schistosomiasis in this period with those associated with 351 funded researchers. A substantially higher productivity and citation impact were found. This consistency of direction points to the positive effect of a period of sustained funding commitment.
\end{abstract}

\section{Introduction}

\section{Science evaluation}

If the volume of publications is a yardstick, research evaluation is fast becoming a regular part of any science policy toolkit. Evaluation methods have been categorized into four types: peer reviews, interviews and questionnaires, quantitative methods, and case studies and histories. ${ }^{1}$ Specifically, the search for objective ways to measure the output and quality of science has resulted in a wealth of literature on quantitative methods. In the last few years, several authors reviewed the literature extensively, summarizing the techniques, surveying the range of applications, citing their strengths and limitations, and exploring the complex issues which form the basis of each method. ${ }^{14}$ Furthermore, the collected work from a conference edited by Elkana and his colleagues and the more recent Handbook present a comprehensive view on the rationale, limitations, and techniques of bibliometric measures as quality indicators. ${ }^{5-6}$

¥ Dedicated to the memory of Michael J. Moravcsik

- This publication is supported in part by a NIH grant RO1-LM-04680 from the National Library of Medicine. 
Not surprisingly, many offer reasons for the intense interest in the development of measurable science indicators. ${ }^{7-8}$ On the one hand, the recent decade's decline in global economy has forced painful limitations on funds for research. On the other hand, the high cost of doing research is associated with many research areas which demand expensive facilities. Additionally modern society presents many challenges resulting in growing needs for new research. It is a classic problem of allocation of limited resources which has intensified the need for science policy research. Consequently, several types of science evaluations are needed. "Picking the winners" applies to research proposals evaluation. A monitoring function is useful for ongoing research projects. Finally, assessment of past research performance and funding decisions is often used to justify continuing support of research programs and plan research agendas.

Specific aspects of quantitative evaluation are of interest to different groups. A large number of papers reviewed are devoted to the development of indicators of science quality so that they may be utilized to augment the traditional peer review mechanism. ${ }^{9-13}$ These are based on bibliometric data, namely, publications and citations. Funding organizations in Europe, notably in Great Britain and the Netherlands, have been active in developing evaluative methods to assess performance of research centers, university departments, pharmaceutical companies, and even science outputs on the national level. ${ }^{14-17}$ Others are interested in bibliometric measures to track the effectiveness of research programs and research fields. ${ }^{18-19}$ Still others are interested in the use of bibliometric data to assess the benefits of research funding. ${ }^{20}$ Two fundamental distinctions have been noted in these pursuits. ${ }^{1}$ The first is rooted in the social value of science. In other words, is the society deriving useful knowledge from science? This is a basic question of social accountability. The second is the relationship of social needs and their economic requirements. Since cost is associated with all benefits, resource allocation to science must rest with the priorities appropriately set by society.

\section{Review of relevant works}

As funded projects have to survive the scrutiny of peer review, they are expected to make significant contribution to new knowledge. Yet computing an average return based on total investment dollars cannot fully assess the benefits accrued from knowledge gain. It is difficult to place a precise value on such public good as health, education, and productivity. According to King, relatively few recent studies have related research inputs to outputs. ${ }^{2}$ Typically retrospective assessment is sought by funding agencies to assess the impact of research programs. Data are often critical in 
the continuance of fund allocation. In 1964, two papers with direct bearing on the role of research support by the National Institutes of Health were published. Orr provided quantitative data relating the magnitude of research expenditures in the Extramural Programs of the National Institutes of Health to document output. ${ }^{21-22}$ These publications were directly attributable to awards made in the period 1951 to 1961. A decade later, a series of papers emanated from Narin and his associates at CHI Research. The group developed a number of bibliometric evaluative measures, focusing on the journal as a basic unit of analysis. ${ }^{23-24}$ They identified the type of papers which resulted from NIH support as well as the quality of journals in which they appeared. One reported that the magnitude of support correlated positively with number of publications and with the quality of the institution where the research was performed. ${ }^{25}$ A high correlation of 0.95 was found between the amount of $\mathrm{NIH}$ funding and the number of biomedical publications for 132 universities in the United States. And for $\mathbf{5 2}$ hospitals, which have received NIH funding, a correlation of 0.89 was shown. Similar strength of correlation between R\&D expenditures and the quantity and visibility of scientific publications was also found in other scientific areas. ${ }^{26}$ In two other studies, the impact of the Intramural and Extramural programs of the National Institutes of Health was shown to be substantial. ${ }^{27-28}$ A significantly positive influence of NIH support on biomedical research was reported. Recently, based on more refined measures, a correlation coefficient of 0.95 between NIH funding level and the quantity of biomedical publications from 120 U.S. medical schools provides corroborating evidence. ${ }^{29}$ These studies point to the positive effects of federal funding especially on biomedical research.

\section{Nature of bibliometric measures}

As noted before, two types of bibliometric data are commonly used. Publication counts are used as proxy for productivity, and citations for quality. Although there are problems associated with both data sources, there is hot debate on the use of citations as measures of quality. ${ }^{30-32}$ Recently, the term "quality" has been replaced by "impact". Although the change in term seems to have lowered the voices of some critics, both terms are still ambiguous. Citation is a complex social process, making it far from being a clear unambiguous indicator of "quality", "impact", "influence", "visibility", or "utility". Cautionary notes against adopting any one indicator as the sole measure of worth have become standard in the literature. Concepts such as productivity, quality, and impact can only be partially captured by publication counts and citation frequencies. Nevertheless, even the critics have to concede that for the moment, publications and citations remain the most reliable convenient measure of 
quality in science. ${ }^{33}$ They are good approximations. Irvine and Martin urged the simultaneous use of multiple indicators and adoption of "converging partial indicators" as a more valid strategy. All agree that used with reservation and with caution, they can be tools in the hands of knowledgeable decision-makers.

This paper reports on an effort to address the relationship between a major funding commitment to the study of a disease and its outcome as indicated by the publication output by the sponsored scientists. The study attempts to shed light on the impact of funding on research productivity and quality.

\section{Research design}

\section{Schistosomiasis and its data sources}

This study narrowly focus on research funding and research outcome in the form of publications on a major tropical disease. Its scope is limited to comparison of performance measures within a field of study, schistosomiasis research. This selection is motivated by several factors. It is a medical subject of international concern and significance. It has enjoyed a long history of support. As an example, the Great Neglected Disease Research Network Program of the Rockefeller Foundation has supported major research institutes in Egypt, Thailand, Mexico, Australia, Israel, Sweden as well as Great Britain and the United States continuously for eight years. Also, since a decade is usually not a long time in order to develop tools for medical diagnosis and disease control, a sustained period of support should also be examined in light of a similarly long span of publication activities. A substantial body of publication exists over a long period of time. Finally, as a well-defined area of investigation, medical subject headings have been established, making the compilation of a comprehensive database for study possible. This subject appears to have the requisite characteristics for valid bibliometric analyses.

Schistosomiasis is a parasitic disease, also known as bilharziasis. It is a group of chronic disorders caused by small parasitic flatworms, species of the family Schistosomatidae. It has been identified as one of the six great neglected diseases by the Rockefeller Foundation and it has also been targeted as one of the six disease groups by the Tropical Disease Research Program of the World Health Organization. This is a serious parasitic disease affecting vast numbers of people many of whom live in remote areas without health services. Thus, an accurate count of the actual affected individuals is impossible. In 1982, 50 million people were 
estimated to be at risk by World Health Organization. ${ }^{34}$ It has infected more than 200 million people. 35

Research activities focus on prevention, diagnosis, treatment, and control of the disease and all clinical aspects have a major impact on public health. While progress in chemotherapy has taken place, increasingly real gain in combating the disease has been derived from immunology and vaccine research. Advances in basic biomedical research and knowledge on parasite and host mechanisms interactions are considered key to research success. Four major funding organizations have targeted specific support for research in the disease for over a decade. They were the Edna McConnell Clark Foundation, the National Institutes of Health, the World Health Organization, and the Rockefeller Foundation. A 17 year funding data totalling over 78 millions were collected. The awards were made to 351 individuals for the years 1970 through 1986.

The second source of data came from the Medline database. Its coverage of tropical diseases is comprehensive. The schistosomiasis literature has been studied in the past. ${ }^{36}$ Compilation of the authoritative bibliography was based mainly on searches on Medline. ${ }^{37}$ Replicating the broad search resulted in papers on the parasite, the snails as the intermediary host and all other related organisms as well as on immunological studies, drug and therapeutic research. Thus a near-complete database on the subject has been compiled. It contains a total of 8,118 publications published from 1966 through 1986.

\section{Bibliometric indicators used}

The study of the relation between effort and outcome necessitates operationalizing these concepts. Numerous unresolved problems are associated with establishing valid measures of both input and output. Conceptually, expenditure, equipment, laboratories, manpower, supporting staff, and even the quality of research environment could be considered variables of research input. This study chose to operationalize input as research grant levels in terms of dollars spent, and manpower in terms of the number of researchers who published at least one paper in the subject before 1987. Since awards from all four agencies were reported in U. S. dollars, there was no need to normalize different currencies.

A number of indicators were used to monitor and assess research output. They are:

1. Publication count as an indication of individual and group productivity;

2. The average impact factor per paper as an index of the quality of publications produced by groups of biomedical scientists; 
3. Citation count of cited authors and author groups as an indication of influence of individuals and of groups; and

4. Citation made to individuals and to groups by state-of-the-art reviews as an indication of impact.

The general strategy used is one that compares the quality and quantity of output associated with the total set of authors in the field with a smaller subset of publications by those who are also recipients of research grants.

Funding data for the period 1970-1986 were obtained from each of the four funding agencies. From these lists of grants, only research projects on schistosomiasis were selected. For each agency, a list was compiled containing the amount of the award, names of principal investigators, and the year of the award. Finally, the four lists were merged. From the merged list, a separate name list was generated. A total of 812 grants was made to 351 individuals.

The master data file was downloaded from Medline. It contains the schistosomiasis literature published from 1966-1986. Each item has been indexed under the Medical Subject Heading "schistosomiasis" or any of the more specific entries. Using the 351 names, a subset of records was extracted from the master data file. The author field of each item in the subset had to contain at least the name of one grantee. In other words, any bibliographic item in this subset had to have at least one author who had received one or more awards from the funding group. A total of 2,971 publications was associated with this group of 351 grantees.

To compare bibliometric characteristic of the master data file with the file associated with the grantees, four name lists were created. From the master file, two author lists were extracted. The first contained all unique names which appeared in the author field of the database. The second consisted of only those that appeared as senior authors in the master file. Similarly, two name lists were extracted from the grantee subfile.

Data from the master file represent characteristics of the "average" research output and the "average" author active in schistosomiasis in the 17 years duration. The analysis of the grantee subfile will yield information on the authors and literature associated with funded research. Comparison of the two groups are made in terms of their relative productivity, quality of their publication output, influence of their work as measured by citation frequencies, and relative impact by the number of "votes" cast by state-of-the-art reviews of the subject.

Accordingly, four sets of analysis were performed using the four types of outcome indicators: (1) productivity, (2) quality, (3) influence, and (4) impact. 


\section{Analysis}

\section{Productivity analysis}

\section{a. Expenditure and document output}

Figure 1 shows the total actual dollars spent in a 17 year period from three of the four funding sources. Funding data from one source was in aggregate form. Over 78 millions were awarded. A steady growths of support is obvious. The peak was reached in 1984. The last year saw a decline, but the data may not reflect the total research support since the MacArthur Foundation has assumed an important role in the support of schistosomiasis research since 1985. However, in spite of this substantial amount, Fig. 1 also shows that if adjusted for inflation, the real purchasing power in terms of constant dollars has been kept relatively constant for over a decade with an exceptionally high level in 1979.

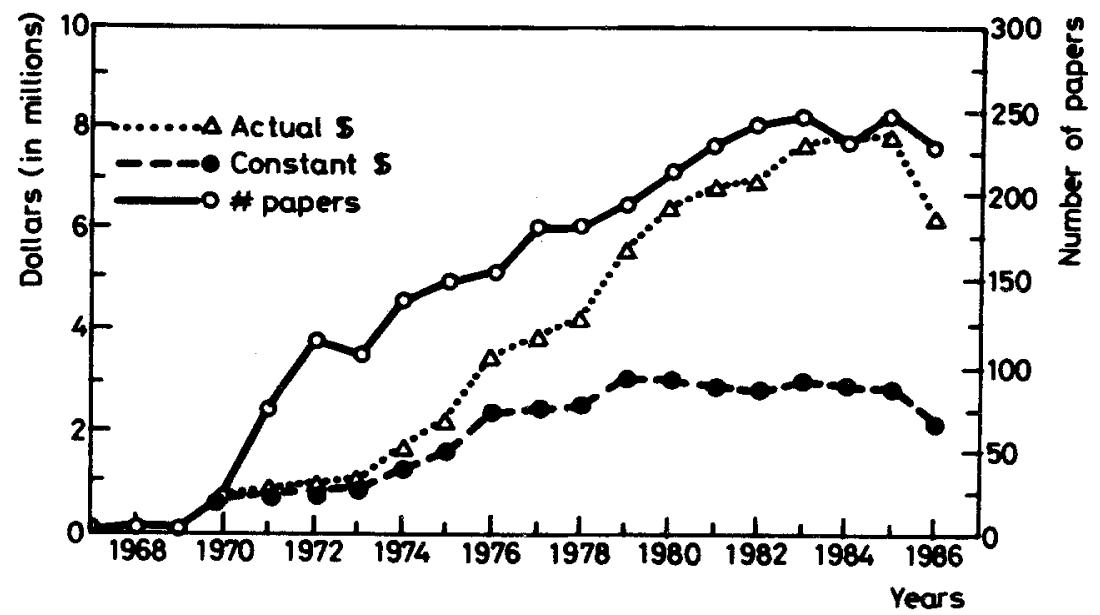

Fig. 1. The total actual dollars and constant dollars spent during in the period of 17 years

Figure 2 depicts the distribution of the yearly publications and the grantee subset over the entire period. There is an outburst of document output in 1971, indicating a sudden interest in the subject as a research area, perhaps attracted by the availability of substantial funding. There is an obvious upward trend in output in the period shown. One is immediately struck by the large proportion of publications associated with the grantees. For every year since 1970, the grantees and their collaborators contributed an average of $36.9 \%$ of the literature. The relative size of the grantee 
subfile ranges from $27.7 \%$ in 1972 to $45.5 \%$ in 1983 . Correlation coefficients of 0.83 and 0.93 are found between annual expenditures, and the yearly total publication output and those from its author subset respectively. Similar correlations computed for the adjusted expenditure figures show the corresponding values of $\mathbf{0 . 7 5}$ and $\mathbf{0 . 9 2}$. Magnitude of funding and publications associated with the sponsored researchers shows a stronger correlation.

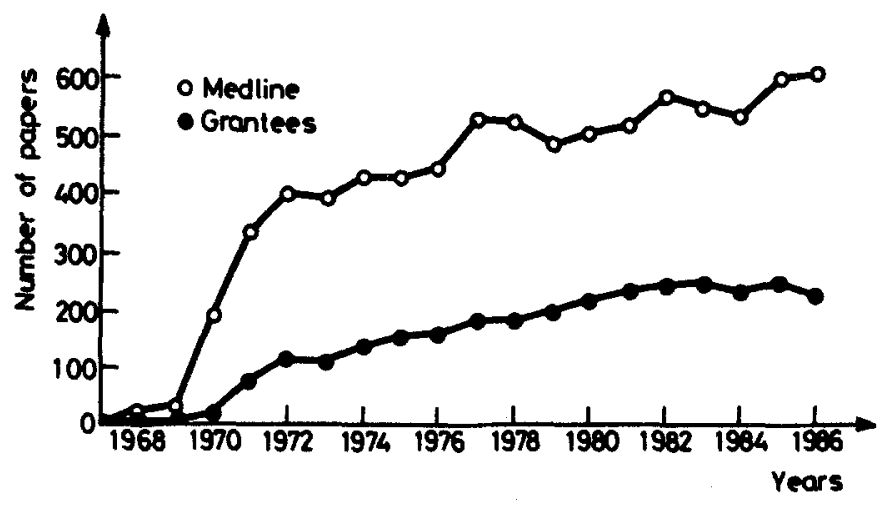

Fig. 2. Annual publications of schistosomiasis literature us those contributed by grantees

\section{b. Author productivity}

In terms of author productivity, a comparison was made on the average productivity on the two groups. The relative degree of concentration of contribution by the top producers in the two sets was also analyzed.

Methodologically, there are several problems in the attribution of multipleauthored publications. ${ }^{38} \mathrm{~A}$ normal count assigns a paper to each name attached to the paper regardless of the number of coauthors or the relative position of the name in the author list. A straight count assigns each paper only to its senior author. An adjusted count credits the authors fractional authorship according to the number of coauthors in the paper. Even if one could attach a higher weight to the senior author in the productivity computation, the relative effort expended by each coauthor is unaccounted for. The order of names listed in publication is not used consistently among authors and between fields. Thus there is no entirely satisfactory method in the attribution of published works.

Fortunately, whichever method of publication assignment is used, the productivity distribution remains largely the same. As summarized by Fox, author productivity adheres stubbornly to two features, namely, a low rate of productivity of the average 
author in a subject group, and a characteristically high degree of variation among the author group. ${ }^{39}$ In other words, no matter how large a body of literature exists for a subject, the average author in the field produces one or two papers, while a large proportion of the literature is produced by a small elite. An inverted $\mathrm{J}$ curve characterizes author productivity.

Overall statistics of the two data sets are as follows. There are 9,916 unique names in the total schistosomiasis literature. Only 3,803 are first authors. Names of the 9,916 authors appeared 23,938 times in the data file of 8,118 publications. In Price's usage of the term "authorship," an average of 2.41 authorship is found. ${ }^{40}$ In other words, the name of each author appeared an average of 2.41 times. The average paper per author is 0.82 and with a higher average of 2.11 papers for those who published as first authors. (See Table 1.)

Table 1

Author productivity data for the schistosomiasis authors, grantees, and their collaborators

\begin{tabular}{|c|c|c|c|}
\hline & \multirow{2}{*}{$\begin{array}{c}\text { All publications } \\
\text { Authors }\end{array}$} & \multicolumn{2}{|c|}{ Sponsored literature } \\
\hline & & Collaborators & Grantees \\
\hline $\begin{array}{l}\text { Number of } \\
\text { papers }\end{array}$ & 8,118 & 2,971 & 2,971 \\
\hline $\begin{array}{l}\text { Number of } \\
\text { authors }\end{array}$ & 9,916 & 2,569 & 351 \\
\hline $\begin{array}{l}\text { Number of } \\
\text { authorship }\end{array}$ & 23,938 & 9,475 & 4,089 \\
\hline $\begin{array}{l}\text { Average } \\
\text { authorship }\end{array}$ & 2.41 & 3.69 & 11.65 \\
\hline $\begin{array}{c}\text { Average } \\
\text { papers }\end{array}$ & 0.82 & 1.16 & 8.46 \\
\hline $\begin{array}{l}\text { No. of papers } \\
\text { (1st author) }\end{array}$ & 8,118 & 2,971 & 1,583 \\
\hline $\begin{array}{l}\text { No. of 1st } \\
\text { author }\end{array}$ & 3,803 & 969 & 233 \\
\hline $\begin{array}{r}\text { Mean papers } \\
\text { (1st author) }\end{array}$ & 2.13 & 3.07 & 6.79 \\
\hline
\end{tabular}

On the other hand, 2,569 unique names are associated with the 2,971 publications from the grantee subfile. This means that the 351 grantees of the four funding sources collaborated with 2,218 other authors. A total of 9,475 authorship yielding a higher average authorship rate of 3.69. Of the 2,569 collaborators, 969 are senior authors of which 233 are grantees. A higher average of 1.16 papers per collaborator is computed. If attribution is given only to senior authors, an average of 3.07 papers 
per collaborator in the grantee subgroup is compared with 2.11 for the average schistosomiasis author.

Limiting the analysis to only the 351 grantees, an average of 8.5 papers $(2,971 / 351)$ are associated with each grantee. More specifically, one also finds that their names have appeared a total of 4,089 times resulting in an average authorship of 11.65. Two-thirds or 233 of the grantees published as senior authors in 1,583 out of the 2,971 papers. Thus grantees who are first authors have an extraordinary average of 6.79 papers to their credit. This is twice as many as that produced by authors associated with the grantee subfile, and three times of the number of papers by the "average" first author. These computations were averaged over all 351 grantees.

Quite unexpectedly, no publication was found for 77 of the 351 grantees. A check with Medline found that many are prolific authors active in other tropical diseases and in basic biochemical and pharmaceutical research. Funding data provided a partial explanation in that a sizable grant may list a single individual as the principal investigator, but may study aspects relating to several tropical diseases. Each subproject was conducted by a separate research team. The principal investigator is usually an expert in one of these areas, not necessarily in schistosomiasis. Thus he may be a prolific author but not publish a single paper in schistosomiasis. In addition, the World Health Organization is particularly active is supporting works conducted by researchers in their native countries. Non-English outlets may have been used and they may not have been indexed by Medline.

In terms of the degree of variation in author productivity, Table 2 shows a highly skewed distribution in that $10 \%$ of the top schistosomiasis authors are associated with $47 \%$ of the total literature. A similar proportion is found for the grantee subfile showing that $11 \%$ of authors are responsible for nearly half of the items. Thus the same patterns of low rate of paper per author and a highly unequal distribution of productivity among scientists are evident in the schistosomiasis authors.

Thus far, this data provide no indication of quality. Yet, every year for over ten years a small number of funded researchers, which comprises only $3.5 \%$ of the total population of schistosomiasis authors, is linked to over one-third of the literature. More to the point, there is an overwhelming representation of grantees among the most productive authors in Table 2. Using the normal count method in which each paper is assigned to every name in the author list of a paper, Table 2 shows that the top authors are dominated by recipients of grants from the four funding sources. Among the nearly 10,000 schistosomiasis authors, 132 are associated with the top quarter of the literature. An overwhelming 72 of these top producers are grantees. Using the method of straight count, assigning each paper only to the senior author, 
an even stronger concentration of output rests with the grantees. (See Table 3.) Of the 172 first authors responsible for the top $26 \%$ of the total literature, 135 of them are grantees. Although sponsored researchers may have a stronger obligation to publish their research results, this high degree of concentration of funded researchers in the top authors in the field points to an usually high level of productivity. Furthermore, a higher average contribution per author is consistently found in the literature associated with the grantee data file.

Table 2

Total schistosomiasis author productivity and those associated with sponsored research (1966-1986)

\begin{tabular}{|c|c|c|c|c|}
\hline $\begin{array}{c}\text { No. of } \\
\text { authorship }\end{array}$ & $\begin{array}{l}\text { No. of } \\
\text { authors }\end{array}$ & $\begin{array}{l}\text { No. of col- } \\
\text { laborators }\end{array}$ & $\begin{array}{l}\text { No. of } \\
\text { grantees }\end{array}$ & Names \\
\hline 170 & 1 & 1 & 1 & ${ }^{*}$ Capron A \\
\hline 113 & 1 & 1 & 1 & *Warren KS \\
\hline 92 & 1 & 1 & 1 & Mahmoud AA \\
\hline 87 & 1 & 1 & 1 & ${ }^{*}$ Colley DG \\
\hline 80 & 1 & 0 & 0 & Pellegrino J \\
\hline 78 & 1 & 0 & 0 & Cheever AW \\
\hline 66 & 1 & 0 & 0 & Katz N \\
\hline 65 & 1 & 1 & 1 & Smithers SR \\
\hline 62 & 2 & 2 & 2 & $\begin{array}{l}\text { *Sher A } \\
\text { *Webbe G }\end{array}$ \\
\hline 61 & 1 & 1 & 1 & "Butterworth AE \\
\hline 60 & 2 & 1 & 1 & $\begin{array}{l}\text { *Capron } \mathrm{M} \\
\text { Farid Z }\end{array}$ \\
\hline 54 & 1 & 1 & 1 & *Bueding E \\
\hline 52 & 1 & 0 & 0 & Sturrock RF \\
\hline 51 & 1 & 1 & 1 & 'Deelder AM \\
\hline 49 & 2 & 2 & 2 & $\begin{array}{l}\text { "Boros DL } \\
\text { "Hillyer GV }\end{array}$ \\
\hline 48 & 1 & 0 & 0 & Bassily S \\
\hline 43 & 4 & 4 & 4 & $\begin{array}{l}\text { *Bennett JL } \\
\text { "Frandsen F } \\
\text { *McLaren DJ } \\
\text { "Tayior MG }\end{array}$ \\
\hline 42 & 3 & 3 & 3 & $\begin{array}{l}\text { *Gazzinelli G } \\
\text { *Higashi GI } \\
\text { *James SL }\end{array}$ \\
\hline 41 & 2 & 2 & 2 & $\begin{array}{l}\text { *David JR } \\
\text { *Jordan P }\end{array}$ \\
\hline $\begin{array}{l}40 \\
39\end{array}$ & $\begin{array}{l}1 \\
1\end{array}$ & 1 & 1 & $\begin{array}{l}\text { 'Lewert RM } \\
\text { Coelho PM }\end{array}$ \\
\hline 38 & 2 & 1 & 1 & $\begin{array}{l}\text { Dessaint JP } \\
\text { "Kuntz RE }\end{array}$ \\
\hline 37 & 4 & 4 & 4 & $\begin{array}{l}\text { *Dean DA } \\
\text { * Nelson GS } \\
\text { *Phillips SM } \\
\text { *Upatham ES }\end{array}$ \\
\hline 36 & 3 & 2 & 1 & Blas BL \\
\hline
\end{tabular}


Table 2 (cont.)

\begin{tabular}{|c|c|c|c|c|}
\hline $\begin{array}{c}\text { No. of } \\
\text { authorship }\end{array}$ & $\begin{array}{l}\text { No. of } \\
\text { authors }\end{array}$ & $\begin{array}{l}\text { No. of col- } \\
\text { laborators }\end{array}$ & $\begin{array}{l}\text { No. of } \\
\text { grantces }\end{array}$ & Names \\
\hline $\begin{array}{c}35 \\
\\
34 \\
33 \\
\\
32 \\
31 \\
30 \\
29 \\
28 \\
27 \\
26 \\
25 \\
24 \\
23 \\
22 \\
21 \\
20 \\
19 \\
18 \\
17 \\
16 \\
15 \\
14 \\
13 \\
12 \\
11 \\
10 \\
9 \\
8 \\
7 \\
6 \\
5 \\
4 \\
3 \\
2 \\
1 \\
0\end{array}$ & $\begin{array}{r}1 \\
2 \\
1 \\
7 \\
3 \\
1 \\
3 \\
5 \\
6 \\
5 \\
7 \\
5 \\
9 \\
13 \\
11 \\
11 \\
14 \\
19 \\
17 \\
27 \\
18 \\
28 \\
39 \\
38 \\
50 \\
57 \\
72 \\
97 \\
130 \\
214 \\
361 \\
579 \\
1,455 \\
6,569\end{array}$ & $\begin{array}{r}1 \\
\\
2 \\
4 \\
4 \\
2 \\
3 \\
3 \\
4 \\
2 \\
2 \\
3 \\
7 \\
9 \\
10 \\
9 \\
3 \\
8 \\
9 \\
12 \\
11 \\
6 \\
24 \\
23 \\
14 \\
19 \\
23 \\
45 \\
45 \\
73 \\
127 \\
219 \\
426 \\
1,383\end{array}$ & $\begin{array}{r}0 \\
\\
1 \\
4 \\
2 \\
1 \\
3 \\
3 \\
3 \\
2 \\
2 \\
3 \\
4 \\
5 \\
6 \\
7 \\
3 \\
7 \\
4 \\
9 \\
6 \\
3 \\
10 \\
10 \\
7 \\
10 \\
8 \\
10 \\
6 \\
16 \\
15 \\
22 \\
23 \\
29 \\
77\end{array}$ & $\begin{array}{l}\text { Mousa AH } \\
\text { "Von Lichtenberg F } \\
\text { Bout D } \\
\text { "Doenhoff MJ } \\
\text { Joseph M } \\
\text { Simphson AJ } \\
\text { Bickle QD } \\
\text { Da Silva LC } \\
\text { "Cook JA }\end{array}$ \\
\hline & 9,916 & 2,569 & 351 & \\
\hline
\end{tabular}

*Identifies the grantees.

Each appearance of an author's name constitutes an authorship. (9,916 authors appeared 23,938 times produced 8,118 papers. 2,569 collaborators appeared 9,475 times produced 2,971 papers). 
M.L. PAO: RELATIONSHIP BETWEEN FUNDING AND PUBLICATIONS

Table 3

Author productivity of first named schistosomiasis authors, grantees, and their collaborators (1966-1986)

\begin{tabular}{|c|c|c|c|c|}
\hline $\begin{array}{l}\text { No. of } \\
\text { papers }\end{array}$ & $\begin{array}{l}\text { No. of } \\
\text { authors }\end{array}$ & $\begin{array}{l}\text { No. of colla- } \\
\text { borators }\end{array}$ & $\begin{array}{l}\text { No. of } \\
\text { grantees }\end{array}$ & Names \\
\hline 38 & 2 & 1 & 1 & \multirow{29}{*}{$\begin{array}{l}\text { "Hiller GV } \\
\text { Cheever AW } \\
\text { "Warren KS } \\
\text { * Capron A } \\
\text { *Colley DG } \\
\text { Sturrock RF } \\
\text { "James SL } \\
\text { "Deelder AM } \\
\text { "Mahmoud AA } \\
\text { Xiao SH } \\
\text { Katz N } \\
\text { "Bogitsh BJ } \\
\text { "Hsu SY } \\
\text { "Andrade ZA } \\
\text { "Coles GC } \\
\text { "Kuntz RE } \\
\text { "Basch PF } \\
\text { "McLauren DJ } \\
\text { "Sher A } \\
\text { "Taylor MG } \\
\text { "Upatham ES } \\
\text { Bout D }\end{array}$} \\
\hline 37 & 1 & 1 & 1 & \\
\hline 28 & $i$ & 1 & & \\
\hline 27 & 2 & 1 & 1 & \\
\hline 25 & 1 & 1 & 1 & \\
\hline 24 & 1 & 1 & 1 & \\
\hline 23 & 2 & 1 & 1 & \\
\hline 22 & 1 & 0 & 0 & \\
\hline 21 & 2 & 2 & 2 & \\
\hline 19 & 3 & 3 & 3 & \\
\hline 18 & 6 & 5 & 5 & \\
\hline 17 & 7 & 4 & 4 & \\
\hline 16 & 6 & 2 & 1 & \\
\hline 15 & 5 & 6 & 3 & \\
\hline 14 & 4 & 2 & 2 & \\
\hline 13 & 10 & 4 & 4 & \\
\hline 12 & 11 & 1 & 1 & \\
\hline 11 & 23 & 15 & 13 & \\
\hline 10 & 21 & 11 & 10 & \\
\hline 9 & 27 & 14 & 12 & \\
\hline 8 & 36 & 21 & 15 & \\
\hline 7 & 33 & 16 & 11 & \\
\hline 6 & 60 & 29 & 15 & \\
\hline 5 & 76 & 32 & 18 & \\
\hline 4 & 150 & 46 & 23 & \\
\hline 3 & 255 & 89 & 21 & \\
\hline 2 & 512 & 172 & 25 & \\
\hline 1 & 2,545 & 488 & 38 & \\
\hline \multirow[t]{2}{*}{0} & & & 118 & \\
\hline & 3,803 & 969 & 351 & \\
\hline
\end{tabular}

*Identifies the grantees. 


\section{Quality analysis - Average impact factor per paper}

Bibliometric indicators of publication quality are commonly based on two types of data, namely, citation frequency of journals and citation counts of the papers themselves. To analyze large data sets, journal citation data are often used as an indirect indicator of publication quality. Many studies have shown positive relationship between peer assessment of journal impact and the measures derived from journal citations. ${ }^{41}$ This sections presents a comparison of the relative "quality" of the master data set with the grantee subfile using the average impact factor per paper as a measure.

It is commonly assumed that prestigious journals impose stricter than average guide-lines for the quality of the papers they publish. Thus using journal citation as a proxy for peer judgment, "impact factor" was the first major attempt to assign a qualitative index to a given journal. It is a normalized measure with respect to the size of the journal. The data are easily available. Yet this measure is limited in three ways. Although a manual count of the section listing journals with non-zero impact factors in the 1968 and 1987 Journal Citation Reports shows 4,316 and 4,332 journals respectively, many journals from non-US countries are not included. Secondly, crossdisciplinary comparisons of journals by impact factors are meaningless as citation practices differ substantially among fields. Of special concern to this study, it is commonly acknowledged that relevant papers on a given subject are unevenly distributed among many journals. Hence the relative standing of a given journal with respect to a given subject depends on the number of relevant papers it published as well as on the overall quality of the journal. Being "a measure of the frequency with which the average article in a journal has been cited in a particular year," the impact factor gives the average citation rate. Equal weight is assigned to each article in the journal regardless of its relevance to subject in question. Suppose the Joumal of Immunology has an high impact factor of 6.48 , and it only publishes one paper on gene coding in the last five years. As far as that topic is concerned, the high impact factor is not indicative of its relatively low importance to gene coding.

Several have refined the use of impact factor. "Influence Measure" incorporates a number of relevant factors with bearing on journal impact. ${ }^{24} \mathrm{CHI}$ Research publishes a list of Journal Influence Measures periodically, but the most recent edition limits its coverage to 3,100 journals. 42 In order to assess the impact of the contribution of university departments, Moed and his associates in the Netherlands introduced the notion of Level Analysis by the use of a weighted-average Journal Citation Score. ${ }^{18}$ This score is computed as a mean citation rate received by the set of papers published by a department weighted by the impact factor of the journals in which 
they appeared. This provides a reference point by which the actual citation rate a publication group may be judged with respect to the discipline. Extensive development of measures in the evaluation of national scientific output has led Schubert and his associates to advocate relative indicators. ${ }^{13}$ In an earlier paper, the Mean Impact Factor, similar to the Journal Citation Score, was used by Schubert as one of four bibliometric indicators. ${ }^{43}$ Since then the mean impact factor is considered the expected citation rate of a group of paper. It acts as an a priori baseline for fielddependent comparison. Both the actual and expected citation ratios have been incorporated into a single measure, known as Relative Citation Ratio.

In this study, the concern is to compare the "quality" of publications from two document sets in the same discipline. The average impact factor per paper incorporates two characteristics, namely, the magnitude of output, and the average citation rate of the journals in which the papers appeared. It is computed by taking the cumulative sum of the product of the number of relevant papers in each journal and its impact factor, and then dividing the cumulative sum by the total number of papers in the set. Journal impact factors are employed as weights attached to papers in each set. The computational procedure is similar to the calculation of the weighted-average Journal Citation Score:44

$$
\operatorname{AvI} \mathbf{P}=\stackrel{i}{\Sigma}\left(\mathrm{IF}_{\mathrm{a}} \cdot \mathrm{n}_{\mathrm{a}}\right) / \mathrm{N}
$$

where Av I/P is the average impact per paper for a given group of articles,

$i$ is the total number of journals in the group,

$\mathrm{IF}_{\mathrm{a}}$ is the impact factor of Journal a,

$\mathrm{n}_{\mathrm{a}}$ is the number of relevant articles in Journal a,

$\mathrm{N}$ is the total number of relevant articles published by $\mathrm{i}$ number of journals.

Thus a single numeric value incorporates the volume of relevant papers in a set weighted with the impact factor of the journal in which each paper appeared. Computed for papers in a subset and for the entire set, an equitable comparison could be made.

From the master data file and the grantee subfile, two corresponding journal frequency distributions were created. Table 4 shows a total of 938 journals in the total schistosomiasis literature. Of these, 285 journals were responsible for the 2,971 papers associated with the grantees. With the impact factor data from the Journal Citation Report, in theory the average impact factor per paper could be computed for each list. For comparative purposes, the average impact factor for the top half of 
Table 4

Average impact factor per paper for the top schistosomiasis journals (1966-1986)

\begin{tabular}{|c|c|c|c|c|c|}
\hline Journals titles & Rank & $\begin{array}{l}\text { Medline } \\
\text { No. of } \\
\text { article }\end{array}$ & Rank & $\begin{array}{c}\text { Grantees } \\
\text { No. of } \\
\text { article }\end{array}$ & $\begin{array}{c}\text { Impact } \\
\text { Factor } \\
1987\end{array}$ \\
\hline Am J Trop Med Hyg & 1 & 507 & 1 & 340 & 1.86 \\
\hline T R Soc Trop Med Hyg & 2 & 356 & 3 & 189 & 1.48 \\
\hline J Parasitol & 3 & 339 & 2 & 224 & 0.84 \\
\hline Exp Parasitol & 4 & 249 & 4 & 147 & 1.50 \\
\hline R I Med Trop Sao Paulo & 5 & 213 & 14 & 42 & 0.25 \\
\hline Parasitology & 6 & 185 & 6 & 151 & 1.74 \\
\hline J Immunol & 7 & 182. $(25 \%)$ & 5 & 157. (43\%) & 6.48 \\
\hline Ann Trop Med Parasitol & 8 & 180 & 7 & 97 & 0.68 \\
\hline Bull Soc Pathol Exot & 9 & 138 & 24 & 25 & 0,11 \\
\hline SE Asian J Trop Med PH & 10 & 128 & 12.5 & 47 & $*$ \\
\hline J Helminthol & 11 & 121 & 8 & 77 & 0.46 \\
\hline J Egypt Soc Parasitol & 12 & $118(33 \%)$ & $\cdot$ & $9(52 \%)$ & $*$ \\
\hline J Egypt Med Assoc & 13 & 109 & . & 3 & $*$ \\
\hline Z Parasitenkd & 14 & 106 & 12.5 & 47 & 0.87 \\
\hline Egypt J Bilharz & 15 & 103 & $\cdot$ & 9 & $*$ \\
\hline J Trop Med Hyg & 16 & 100 & 19 & 32 & 0.20 \\
\hline Int J Parasitol & 17 & 93 & 10 & 59 & 1.15 \\
\hline Bull WHO & 18 & 91 & 15 & 37 & 1.28 \\
\hline Chi Sheng Chung Hsueh & 19 & 83 & . & 3 & $*$ \\
\hline East Afr Med J & 20 & 80 & 37 & 14 & 0.09 \\
\hline Trop Geogr Med & 21 & 77 & 27 & 20 & 0.26 \\
\hline Mol Biochem Parasitol & 22 & 72 & 9 & 67 & 3.21 \\
\hline Med Trop (Mars) & 23 & 71 & 31 & 16 & $*$ \\
\hline Cent Afr J med & 24 & 66 & $\cdot$ & 2 & 0.08 \\
\hline S Afr Med J & 25 & 59 & • & $\mathbf{1}$ & 0.51 \\
\hline Acta Trop (Basel) & 26 & 58 & 22 & 28 & 0.88 \\
\hline Ann Parasitol Hum Comp & 27 & 58 & 40 & 13 & 0.39 \\
\hline Parasite Immunol & 28 & 57 & 11 & 52 & 2.20 \\
\hline Yao Hsueh Hsueh Pao & 29 & $56(50 \%)$ & . & $0 .(65 \%)$ & * \\
\hline Rev Saude Publica & 30 & 54 & . & 2 & - \\
\hline$J$ Infect Dis & 31 & 52 & 16 & 35 & 4.36 \\
\hline Tropenmed Parasitol & 32 & 51 & 44 & 12 & 0.84 \\
\hline Br Med J & 33 & 47 & 48 & 11 & 2.75 \\
\hline Lancet & 34 & 47 & 33 & 15 & 13.25 \\
\hline Total journals & & 938 & . & 285 & \\
\hline Total articies & & 8,118 & - & 2,971 & \\
\hline Av IF per paper (25\%) & & 1.81 & & 2.08 & \\
\hline Av IF per paper (33\%) & & 1.43 & & 1.80 & \\
\hline Av IF per paper $(50 \%)$ & & 1.16 & & 1.70 & \\
\hline
\end{tabular}

* Indicates that no impact factor is available.

. Indicates that the rank $>50$. 
the total literature was computed. The computed value is 1.16 . (See Table 4.) Only $3 \%$ or 29 journals were used since they published the top half of the literature. Extracting only those papers associated with the grantee literature, a new average impact factor per paper of 1.70 is calculated for the grantee subset. Obviously, the average impact per paper has a higher value for the literature associated with funded authors. The same procedure was repeated for the top $1 / 3$ and $1 / 4$ of the total literature. Table 4 shows consistently higher values associated with the grantee subfile.

Since the impact factor of any journal varies from year to year, additional computations used the impact factors of the last five years as weights for the papers in the two data files. In every comparison, the average impact factor score for the grantee subset is higher. Furthermore, the stability of the measure was also tested. This was accomplished by computing the two corresponding average impact factors using the same two data files but excluding those from the last year, namely, the 1986 records. It was as if the comparison was done in 1986. By truncating the data file one year at a time, computations of the average impact factor per paper for the two data sets were repeated three additional times. This was done to show if there is stability in the use of the measure. In every comparison, the average impact factor associated with the grantee subset is higher than that derived from the total literature. ${ }^{44}$

A partial qualitative confirmation was sought by examining the journal titles associated with the two data files. Traditional outlets for schistosomiasis research are journals of parasitology and tropical medicine. As noted earlier, in recent years, work on the molecular biology of the parasite has brought considerable success in combating the disease. Funding programs have encouraged research in immunopathologenesis, biochemistry, and in antibody vaccine studies. Among the top 29 journals which covered the top half of the total literature, 24 traditional outlets dominate the field. The remaining five are Experimental Parasitology, Joumal of Immunology, Joumal of Helminthology, Molecular and Biochemical Parasitology, and Parasite Immunology. These new research outlets covered $8 \%$ of the literature. On the other hand, of the 10 journals responsible for half of the literature associated with funded investigators, 4 are journals of immunology, biochemistry, and molecular biology. These four journals published $16 \%$ of the grantee file indicating emphasis targeted by the funding agencies as well as research direction of the field. 


\section{Influence analysis - Citations}

Problems associated with the use of citation counts as indicators of influence and quality are well-known. ${ }^{30-33}$ In the present study it is used as an indicator in the hopes of offering corroborating evidence for results of other indicators. The general plan of citation frequency comparison is adhered to. In this case, the unit of analysis has shifted from the publication to the author. The citation patterns of the 351 grantees are observed and are compared with that derived from a sample of the other authors.

As with other studies, the problem of homographs must be resolved in the data collection procedure. A cited reference homograph refers to the name of a cited author belonging to two individuals. Checks made on the master data file and the grantee subfile show that $78 \%$ and $90 \%$ of the items in the two files respectively contain at least one of the two word stems, "schisto-" and "bilha-" in their titles. Titles of papers tend to refer specifically to the disease. In retrieving the citation frequency data from the online version of the Science Citation Index, citing papers were restricted to only those with either one of two word stems. Yet many basic research such as monoclonal antibody studies are also applicable to other disease entities. This strategy eliminated many relevant citations. On the other hand, the search strategy assures the relevancy of those items retrieved. It was reasoned that since the technique was consistently employed for both groups of authors, proportional loss would occur in both data sets. Since the objective is to detect differences between the influence of the subset and its master set, the relative volume of relevant citations made is more important. Cited references from 1974 through 1988 were collected for each name. Extending two additional years to 1988 provided an adequate lead time for citations to be made. Each retrieved set represents the total influence of the ouvre of each individual.

For comparative purpose, raw citation count is meaningless since citation frequencies vary widely among fields. Since this study compares two author groups in the same field, this is not a concern. However, the Science Citation Index data are limited only to citations made to first authors. This citation limitation must also be resolved. Results from the following analysis had to be restricted to senior authors only. From the grantee subfile, citations to only the 233 senior authors were used. To ensure a fair comparison, a proportional stratified random sample from the master data set was taken. The procedure is as follows: An author frequency distribution was created from the master data file. The list of 3.803 senior author was arranged in descending order of productivity. Authors in each level of productivity can be identified. Those belonging to the grantee subset were marked on the list. For 
example, of the 2,545 authors each contributing a single publication, 30 were identified as grantees. Based on the proportion of grantees found in this level of one paper, a proportional number of the other authors was selected. This procedure is weighted towards representation from the more productive members, since a heavy concentration of grantees is found among the productive schistosomiasis authors. Citations to a total of 221 authors were used to compare with citations to 233 grantees.

A considerably higher average of 81 citations per grantee is found as compared with an average of 39 citations made to an average senior author. This group of grantees were cited more frequently than a representative sample of the other authors active in the same subject. One explanation of the higher citation rate of the grantee is that as more papers are published by an author, more papers from this individual are available to be cited. The average number of papers per author for the two groups are 6.79 and 2.13 for the grantee and the control sets respectively. Pearson tests were performed correlating the number of papers produced with the number of citations received for each of the two groups of senior outhors. A higher coefficient of 0.68 for the grantee compared with 0.41 for the control group. Since the grantee group is considerably more productive, one can speculate that the probability of "influence" by citation may also be much higher among the funded researchers. This comparison fails to offer conclusive evidence that the papers associated with the grantees themselves were more "influential" than those associated with other authors.

\section{Impact analysis - Citations by reviews}

Pao's 1975 study suggests that citations made by reviews may be used as a quality filter. ${ }^{45}$ Review articles provide an overview of recent works in a given subject area. The reviewer "compiles information gleaned from a survey of relevant bibliography into an integrated discussion that is the result of critical assessment of the literature". 46 They often sum up the subject with quantitative and qualitative data. Reviews are generally commissioned works written by authorities in the field. In reference to review articles, Ziman claims that in this type of publication the author is expected "to read all the papers on the subject, give a brief account of their findings, and relate them one to another, noting agreement and contradictions" ${ }^{47}$ Thus, it is a critical summary of the current consensus in some particular field by a subject expert. Pao has shown that there is a positive correlation between works frequently cited by reviews in a subject and works selected by experts in subject bibliographies. The implication is that frequency of citations by reviews is another partial indicator of quality. In building the National Library of Medicine hepatitis 
database, works more frequently cited by reviews formed the basic corpus of representative works on the subject. 48

Fifty-five reviews were identified from the "Bibliography of Medical Reviews" from the annual volumes of the Index Medicus. In this analysis, the individual is the unit of analysis. Since coauthors are not consistently listed, citation data in this analysis were also limited to senior authors. Only reviews of the general topic "schistosomiasis" were selected. They were taken from 1978 through 1988, so that a two year lead time was provided.

Some citations were made to related areas outside of the subject of schistosomiasis. For example, many reported studies of enzymes and of the cloning of antibody cells. The analysis was limited to only those authors identified in the schistosomiasis database. A total of 4,847 citations were made to 1,069 schistosomiasis authors found in the master data file. Thus $11 \%$ of all schistosomiasis authors published 3,593 papers (41\% of the total literature) as senior authors. The reviewers mainly cited works from a prolific group of authors. An average of 4.5 citations were made by the reviewers to this group. Out of the total 4,847 citations, 2,145 were made to 179 grantees. In other words, over half of the grantees were cited by reviews. This select group of grantees published 1,382 papers, nearly half of the grantee subfile, as first authors. They were cited an extraordinarily high average of 12 times in the 55 reviews.

From another perspective, Table 5 shows the citation frequency in which a vast majority of the highly cited authors were also among the sponsored researchers identified in the grantee group. In this highly skewed distribution, $50 \%$ of citations to grantees were made to 15 persons. Specifically, of the top 18 authors who received $25 \%$ of the total citations, 16 are grantees. Of the 84 individuals who received half the total citations, 44 are grantees. Finally, $75 \%$ of the citations were made to 290 schistosomiasis authors, 104 of whom are grantees.

Table 5

Frequency distribution of first authors as cited in 55 medical reviews of schistosomiasis (pub. 1978-1988)

\begin{tabular}{cccl}
\hline $\begin{array}{c}\text { No. of } \\
\text { authors }\end{array}$ & $\begin{array}{c}\text { No. of } \\
\text { grantees } \\
\text { cited }\end{array}$ & $\begin{array}{c}\text { No. of } \\
\text { times } \\
\text { cited }\end{array}$ & Names \\
\hline 1 & 1 & 235 & "Warren KS \\
1 & 1 & 82 & "Mahmoud AAF \\
1 & 1 & 79 & "Colley DG \\
1 & 1 & 72 & "Sutterworth AE \\
1 & 1 & 71 & "Shithers SR \\
1 & 1 & 69 & "Capron A \\
1 & 1 & 68 & \\
\hline
\end{tabular}


Table 5 (cont.)

\begin{tabular}{|c|c|c|c|}
\hline $\begin{array}{l}\text { No. of } \\
\text { authors }\end{array}$ & $\begin{array}{l}\text { No. of } \\
\text { grantees } \\
\text { cited }\end{array}$ & $\begin{array}{l}\text { No. of } \\
\text { times } \\
\text { cited }\end{array}$ & Names \\
\hline 1 & 0 & 64 & Cheever AW \\
\hline 1 & 1 & 58 & *Von Lichtenberg $F$ \\
\hline 1 & 1 & 56 & *Pelley RP \\
\hline 2 & 2 & $\begin{array}{l}53 \\
53\end{array}$ & $\begin{array}{l}\text { "Boros DL } \\
\text { "James SL }\end{array}$ \\
\hline 1 & 1 & 51 & Dean DA \\
\hline 1 & 1 & 47 & ${ }^{*}$ Capron $\mathrm{M}$ \\
\hline 1 & 1 & 46 & * McLaren DJ \\
\hline 1 & 0 & 41 & Vannier WE \\
\hline 1 & 1 & 38 & *Andrade ZA \\
\hline 1 & 1 & 37 & Phillips SM \\
\hline 1 & 0 & 33 & Bickle QD \\
\hline 2 & 1 & $\begin{array}{l}32 \\
32\end{array}$ & $\begin{array}{l}\text { Clegg JA } \\
\text { "Hillyer GV }\end{array}$ \\
\hline \multirow[t]{3}{*}{3} & $\mathbf{0}$ & 31 & Sadun EH \\
\hline & & 31 & Sturrock RF \\
\hline & & 31 & Simpson AJG \\
\hline 1 & 0 & 30 & Katz $\mathbf{N}$ \\
\hline 1 & 0 & 29 & Houba V \\
\hline 1 & 1 & 28 & "Taylor MG \\
\hline \multirow[t]{2}{*}{3} & 2 & $\begin{array}{l}27 \\
27\end{array}$ & $\begin{array}{l}\text { "Dunn MA } \\
\text { "Dissous C }\end{array}$ \\
\hline & & 27 & Dessaint JP \\
\hline \multirow[t]{2}{*}{3} & 3 & $\begin{array}{l}26 \\
26\end{array}$ & $\begin{array}{l}\text { "Damain RT } \\
\text { "Cook JA }\end{array}$ \\
\hline & & 26 & *Jordan P \\
\hline \multirow[t]{3}{*}{3} & 1 & 25 & ${ }^{*}$ Hsu SY \\
\hline & & 25 & Santoro F \\
\hline & & 25 & Nash TE \\
\hline 1 & $\mathbf{0}$ & 24 & Murrel KD \\
\hline \multirow[t]{2}{*}{2} & 2 & 23 & "Nelson GS \\
\hline & & 23 & Webbe G \\
\hline 1 & 1 & 20 & ${ }^{*}$ Smith MA \\
\hline \multirow[t]{3}{*}{4} & 2 & $\begin{array}{l}19 \\
19\end{array}$ & $\begin{array}{l}\text { Ramalho Pinto FJ } \\
\text { Auriault C }\end{array}$ \\
\hline & & 19 & Peters PA \\
\hline & & 19 & Bout D \\
\hline \multirow[t]{2}{*}{3} & 0 & 18 & Grzych JH \\
\hline & & 18 & James C \\
\hline \multirow{5}{*}{5} & 2 & $\begin{array}{l}18 \\
17\end{array}$ & $\begin{array}{l}\text { Joseph M } \\
\text { Kagan IG }\end{array}$ \\
\hline & & 17 & $\begin{array}{l}\text { Kagan IG } \\
\text { Dunne DW }\end{array}$ \\
\hline & & 17 & Maddison SE \\
\hline & & 17 & *Deelder AM \\
\hline & & 17 & *James ER \\
\hline \multirow{5}{*}{$\begin{array}{l}1 \\
6\end{array}$} & 0 & 16 & Kamel I \\
\hline & 4 & 15 & * Harn DFAS \\
\hline & & 15 & Ericson D \\
\hline & & 15 & Mott KE \\
\hline & & 15 & Andrews $\mathbf{P}$ \\
\hline
\end{tabular}


Table 5 (cont.)

\begin{tabular}{|c|c|c|c|}
\hline $\begin{array}{l}\text { No. of } \\
\text { authors }\end{array}$ & $\begin{array}{l}\text { No. of } \\
\text { grantees } \\
\text { cited }\end{array}$ & $\begin{array}{l}\text { No. of } \\
\text { times } \\
\text { cited }\end{array}$ & Names \\
\hline 8 & 2 & $\begin{array}{l}15 \\
15 \\
14 \\
14 \\
14 \\
14 \\
14 \\
14 \\
14 \\
14 \\
14\end{array}$ & $\begin{array}{l}\text { *Kuntz RE } \\
\text { *Bueding E } \\
\text { Harris AD } \\
\text { Adeloye A } \\
\text { *Acher S } \\
\text { Davis A } \\
\text { Reid WA } \\
\text { Lehman JS JR } \\
\text { Pellegrino J } \\
\text { "Lewert R }\end{array}$ \\
\hline 10 & 4 & 13 & \\
\hline 7 & 3 & 12 & \\
\hline 12 & 6 & 11 & \\
\hline 8 & 5 & 10 & \\
\hline 9 & 3 & 9 & \\
\hline 17 & 5 & 8 & \\
\hline 22 & 6 & 7 & \\
\hline 32 & 8 & 6 & \\
\hline 46 & 14 & 5 & \\
\hline 60 & 13 & 4 & \\
\hline 85 & 8 & 3 & \\
\hline 185 & 22 & 2 & \\
\hline 509 & 45 & 1 & \\
\hline 1,069 & 179 & $\begin{array}{l}847 \\
\text { ted }\end{array}$ & \\
\hline
\end{tabular}

One final observation is made concerning the relation of productivity and citations made by reviews. The top $56 \%$ of the schistosomiasis literature were authored by 746 or $20 \%$ of the authors who wrote as first authors. Of the 746 authors, half or 370 were cited by at least one of the 55 reviews between the years 1978 - 1988. These authors published an average of 7.5 papers in which they appeared as senior authors. One-third or 148 of these cited authors have been principal investigators in at least one of the awards made by funding agencies. In other words, among the group of 351 grantees, works from almost half of this group (42\%) were noted in state-of-the-art reviews. If, instead, the top $46 \%$ of the literature were examined, one finds that of the 491 contributors, an even higher $60 \%$ or 292 authors were cited by reviewers. The average productivity is 8.7 papers. A consistently higher citation rate is observed in relation to higher productivity. Even though highly productive authors have a higher probability of being cited by the literature at large, the extraordinary number of citations found in reviews could hardly be attributed to chance. The more productive an author is, the more likely he 
citations from reviews. Thus the use of citation in reviews as an additional quality filter provides further evidence of the impact of research funding.

\section{Conclusion}

This paper began by stating that direct positive effect of research funding on basic research is not easily shown. This study selected a subject literature associated with a major disease with a sustained and strong commitment of research support. A number of indicators of productivity and impact were used, all of which appeared to show a "consistency of direction," an expression used by Koening. ${ }^{49}$ Both the quantity and quality of schistosomiasis research associated with the funded group of scientists appeared to score higher in every comparison made. A similar approach to the method of "converging partial indicators" is applicable here.

Although none of the outcome indicators may be considered entirely persuasive in itself, the direction they all point to show a consistency which is difficult to deny. A substantially large difference is shown in the productivity and quality found in the subset as compared with the "average" contributor to schistosomiasis. The sponsored researchers as a group are highly productive and are more likely to be cited by the review writers and by the field at large. Although the ultimate aim of medical research on a disease is its cure, if not, its eradication, publication is essential to the communication of new findings and knowledge. Thus its magnitude in productivity and impact can be reasonable indicators of the quality of work performed. Results from this study show that publication quality is strongly related to funding. The extraordinary differential can hardly be dismissed as circumstantial. Implications for the huge pay-off of basic research is clear. Again, this study cannot unequivocally show a direct causal relation between funding and research success. However, the overwhelming trend as shown by several partial indicators studied points to the direction of such an effect.

\section{References}

1. T. LuUKKonEN-Gronow, Scientific research evaluation: A review of methods and various contexts of their application, $R \& D$ Management, 17 (1987) No. 3, 207-221.

2. J. KiNG, A review of bibliometric and other science indicators and their role in research evaluation, Journal of Information Science, 13 (1987) No. 3-4, 261-276.

3. H. D. WHIt, K W. MCCAIN, Bibliometrics, In: Annual Review of Information Science and Technology, 24 (1989) 119-186.

4. D. E. Chubin, Research evaluation and the generation of big science policy, Knowledge, Creation, Diffusion, Utilization, 9 (1987) 254-277.

5. Y. E. Elkana, K. Lederberg, R. K. Merton, A. Thackray, H. Zuckerman, (Eds), Towards a Metric of Science: the Advent of Science Indicators, John Wiley, New York, 1978. 
5. Y. E. Elkana, K. Lederberg, R. K. Merton, A. Thackray, H. Zuckerman, (Eds), Towatds a Metric of Science: the Advent of Science Indicators, John Wiley, New York, 1978.

6. VAN RAAN, A. F. J. (Ed. ), Handbook of Quantitative Studies of Science and Technology, Elsevier, The Netherlands, 1988.

7. H. A. AVERCH, Measuring the cost-efficiency of basic research investment: Input-output approaches, Journal of Policy Analysis and Management, 6 (1987) No. 3, 342-361.

8. J. IRVINE, B. R. MARTIN, Assessing basic research; The case of the Isaac Newton Telescope, Social Studies of Science, 13 (1983) 49-86.

9. B. R. MARTIN, J. IRVINE, Assessing basic research: Some partial indicators of scientific progress in radio astronomy, Research Policy, 12 (1983) 61-90.

10. P. VINKLER, Weighted impact of publications and relative contribution score. Two new indicators characterizing publication activity of countries, Scientometrics, 14 (1988) 161-163.

11. M. E. D. KoENIG. Determinants of expert judgment of research performance, Scientometrics, 4 (1982) 361-378.

12. J. IRVINE, B. MARTIN, International comparison of science performance revisited, Scientometrics, 15 (1989) 369-392.

13. A. SCHUBERT, T. BRAUN, Relative indicators and relational charts for comparative assessment of publication output and citation impact, Scientometrics, 9 (1986) 281-291.

14. S. Cozzzns, (Ed. ), Theme section, Social Studies of Science, 16 (1986) 9-147.

15. L. LEYDESDORFF, J. IRVINE, A.F.J. VAN RAAN, (Eds) The relations between qualitative theory and scientometrics methods in science and technology studies, Scientometrics, 15 (1988) Nos 5-6.

16. P. Healey, I. Irving, B. R. Martin, (Ed. ), Scientometrics research in the United Kingdom, Scientometrics, 14 (1988) Nos 3-4.

17. P. VINKLER, Management system for a scientific research institute based on the assessment of scientific publications, Research Policy, 15 (1986) 77-87.

18. H. F. Moed, W. J. M. BuRGer, J. G. Frankfort, A. F. J. VAN RAan, The use of bibliometric data for the measurement of university performance, Research Policy, 14 (1985) 131-149.

19. E. Bujdosó, T. Braun, Publication indicators of relative research efforts in physics subficlds, Journal of the American Society for Information Science, 34 (1983) 150-155.

20. P. R. MCAILISTER, T. CONDON, Econometric analysis of biomedical research publishing patterns, Scientometrics, 7 (1985) 55-75.

21. R. H. OrR, G. Abdin, A. A. Leeds, Generation of information: Published output of U. S. biomedical research, Federation proceedings, 23 (1964) 1297-1309.

22. R. H. ORR, A. A. LeEDS, Biomedical literature: Volume, growth and other characteristies, Federation Proceedings, 23 (1964) 1319-31.

23. F. NARIN, Evaluative Bibliometrics: The Use of Publication and Citation Analysis in the Evaluation of Scientific Activity. contract NSF C-627, NSF, NTIS Accn. \#PB-252399/AS, 1976.

24. F. NARIN, Structure of biomedical literature, Journal of American Society for Information Science, 27 (1976) 25-44.

25. J. D. FraME, F. NARIN, NHH funding and biomedical publication output, Federation Proceedings, 35 (1976) 2529-2532.

26. P. R. MCALuSTER, D. A. WANGER, Relationship between R \& D expenditures and publication output for U. S. colleges and universities, Research in Higher Education, 15 (1981) 3-30.

27. F. NARIN, R. T. SHAPIRo, The extramural role of the NIH as a research support agency, Federation Proceedings, 36 (1977) 2470-6.

28. F. NARIN, S. B. KEITH, The intramural role of the NIH as a research support agency, Federation Proceedings, 37 (1978) 2120-3.

29. P. R. MCALlister, F. NARIN, Characterization of the research papers of U. S. medical schools, Journal of the American Society for Information Science, 34 (1983) 123-131.

30. B. CRONIN, The Citation Process: The Role and Significance of Citations in Scientific Commutation, Taylor Graham, London, 1984. 
33. D. LINDSEY, Using citation count as a measure of quality in science: Measure what's Measureable rather than what's valid, Scientometrics, 15 (1989) 189-203.

34. G. H. REE, Schistosomiasis and human behaviour, Ecology of Disease, 1 (1982) No. 2-3., 131-133.

35. UNDP, World Bank, Special Programme for Research and Training in Tropical Diseases, WHO, Report of the Second External Review Committee, WHO, Geneva, 1988.

36. W. Goffmann, K. S. WARREN, Scientific Information System and the Principle of selectivity, Praeger Press, New York, 1980.

37. K. S. WARREN, V. A. NEWIL, Schistosomiasis: A Bibliography of World's Literature from 1852 to 1962 , Cleveland, CWRU Press, 1980.

38. D. LINDSEY, Production and citation measures in the sociology of science : The problem of multiple authorship, Social Studies of Science, 10 (1980) 145-162.

39. M. F. Fox, Publication productivity among scientists: A critical review, Social Studies of Science, 13 (1983) 285-305.

40. D. J. DE S. Price, D. DE B. BeAvER, Collaboration in an invisible college, American Psychologist, 21 (1966) 1011-1018.

41. P. R. MCAluister, R. C. ANDerson, F. NARIN, Comparing peer and citation assessment of the influence of scientific joumals, Joumal of the American Society for Information Science, 31 (1980) 147-152.

42. E. NOMA, Sibject Classification and Influence Weights for 3,000 Journals, Contract NIH-NO1-OD -52118, NIH Report, 5/8/86. New Jersey, Computer Horizon, Inc., 1986.

43. A. SCHUBERT, S. ZSINDELY, T. BRAUN, Scientometric indicators for evaluating medical research output of mid-size countries, Scientometrics, 7 (1985) 155-163.

44. M.L. PAO, W. Gofrman, Quality assessment of schistosomiasis literature, Information Processing and management, (submitted).

45. M. L. PAO, Quality filtering of biomedical literature, Journal of the Medical Education, 50 (1975) 353-359.

46. B. SNOw, Review articles in Medline: Past and present, Online, 13 (1989) 101-105.

47. J. Ziman, Public Krowledge: The Social Dimension of Science, Cambridge University Press, Cambridge, 1968.

48. L. M. Bernstein, E. R. Segal, C. M. Goldstein, The hepatitis knowledge base: A prototype information transfer system, Annals of Internal Medicine, 93(1 Pt. 2) (1980) 169-181.

49. M. E. D. KoENIG, Bibliometric indicators versus expert opinion in assessing research performance, Journal of the American Society of Information Science, 34 (1983) 136-145. 